\title{
Impact of Urea Molasses Mineral Block and Dewormer on Milk Production and Reproduction Performance of Dairy Animals
}

\author{
Vivek Pratap Singh ${ }^{1}$, R. P. Singh ${ }^{2}$, A. K. $\operatorname{Singh}^{3}$, R. K. Singh ${ }^{4}$, \\ A. K. Srivastav ${ }^{5}$ and S. P. Upadhyay ${ }^{6}$ \\ ${ }^{1}$ SMS-Animal Science, ${ }^{2}$ Sr. Sc. \& Head, ${ }^{3}$ SMS-Agronomy, ${ }^{4}$ SMS-Agri. Extension, \\ ${ }^{5}$ SMS-Horticulture, ${ }^{6}$ SMS-Soil Science, Mahayogi Gorakhnath Krishi Vigyan Kendra, \\ Peppeganj, Gorakhpur, U. P. (273165), India \\ *Corresponding author
}

\section{A B S T R A C T}

\section{Keywords}

UMMB, Dewormer, Milk yield, Reproduction, Dairy Animal

\section{Article Info}

Accepted:

18 May 2020

Available Online:

10 June 2020
An experiment was conducted for a period of 120 daysto study the effect of UMMB as supplementary feeding and deworming on the reproductive performance and milk yield of dairy animals. Twenty milking cows of 4 to 6 years age group were selected randomly with initial average milk production of 6.22 liter per day. Before the start of experiment all the animals were dewormed against internal and external parasites on first day and from next day all the animals were divided in two group viz $\mathrm{T}_{1}$ control (farmers practice) and $\mathrm{T}_{2}$ feeding UMMB $300 \mathrm{~g}$ per day. Observations on all closely monitored dairy animals revealed an average increase of milk production from 0.8 - 1.08liter per animal per day, improvement in health and $90 \%$ animals were comes in heat and conceives in T2 group in the comparison of T1 group. Farmer's practice is not only reduces milk production and increases costs per kg milk, but also affects various physiological functions including long term animal health, fertility and productivity. It is also essential that milk producers feed their animals the nutrients in amounts that match the physiological needs and objective of keeping the animal. It was concluded that anthelmintic drugs decreases the parasitic load and UMMB being a good source of energy, protein and minerals improved milk yield, general health status and reproductive performance of dairy animals.

\section{Introduction}

Animal nutrition is an important factor limiting livestock productivity, and feed costs are considered as the major constraint to raising income from livestock production in India. Dairy animals are fed mainly on byproducts of various food crops, oil seeds and locally grown fodder but these by-products, especially oil seed cakes or meals are not available in sufficient quantity to meet the entire demand of the livestock population. A balanced ration should provide protein, energy, minerals and vitamins from dry fodders, green fodders, concentrates, mineral supplements etc., in appropriate quantities to enable the animal to perform optimally and remain healthy result in low animal growth, poor reproduction, long calving interval, repeat breeding and infertility in animals. 
Animal nutritionists, all over the world, have proved that the nutritive value of crop residues can be enhanced if supplemented with deficient nutrients (Makkar, 2002). Occurrences of diseases are another major factor affecting productivity of livestock, the most frequently reported disease by veterinarians and animal's health service are those, which cause huge economic loss. Disease usually results from a combination of factors including inadequate feeding and low standard of management. Livestock farmers reared the animals are generally fed variable quantity of low quality feed resources like wheat straw and rice straw which are characteristically low in fermentable nitrogen, mineral, and readily available carbohydrate. The nutritive value of crop residues can be enhanced if supplemented with deficient nutrients through easily available feed supplements. Supplementation of urea, molasses and mineral mixture enriched block showed promising results in improving the nutrient utilization, production and reproduction of animals Patil et al., (2017).

Inadequate nutrition is one of the major factors that frequently limit the full utilization of the productive and reproductive potential of livestock in this region. Developing alternate feeding strategies for ruminant by enhancing the nutritive value roughage is of prime importance. A urea molasses mineral mixture blocks (UMMMB) prepared from locally available agricultural byproducts like wheat bran, rice bran, mineral mixture, common salt and molasses has been adoptable feed supplement which improves nutritional status of animals.

\section{Materials and Methods}

Present experiment was conducted on milking cows in the different villages of Gorakhpur district was selected by Mahayogi Gorakhnath Krishi Vigyan Kendra, Peppeganj,
Gorakhpur, Uttar Pradesh, India. Twenty milking cows of 4 to 6 years age group were selected with average milk production of 6.22 liter per day. All animals were randomly divided in to two group having 10 animals in each. First group kept as control $\mathrm{T}_{1}$ (farmer's practice where animals were not offered any kind of supplementation with their daily feed) and second treatment group $\left(\mathrm{T}_{2}\right)$ all the animals were dewormed before to allow to feeding UMMB $300 \mathrm{~g}$ per day in their daily diet for 120 days.

Feeding practices was similar in both the group except feeding of UMMB in treatment group. Feeding of Urea Molasses Mineral Block was started after their calving till 120 days of lactation. Data was collected for milk production and reproductive parameters. Out of milk production parameters daily milk production (lit.), peak yield (lit.) and 120 days milk production (lit.) was noted regularly in whole experiment period of four months. Animals were observed for their first estrous sign after parturition. In reproductive parameters time taken to reach first estrous (days), service period, service per conception and conception rate $(\%)$ was recorded for all animals in both groups. Intensity of estrous sign was also recorded for all cows.

\section{Results and Discussion}

The UMMMB was prepared by cold method by UMMMB making machine prepared by ICAR-Indian Veterinary Research Institute, Bareilly by mixing different ingredients with slight modification as per availability of feed ingredients (Table 1).

\section{Milk production performance}

As shown in Table 2 and graphically depicted in figure 1 animals fed UMMB showed improvements in average daily milk production at different intervals was found 
higher in treatment group than the control group by 6.59 and 6.38 liter, respectively. Beside this, treated animals were produced an average of 7.18 liter milk among 120 days of milking period that was higher in comparison to the control group that produce an average of 5.84 liter milk, respectively. Average daily milk yield and total milk yield was found higher in treatment group and lowest in control group by $17.70 \%$ and $-8.03 \%$, respectively. These results were in agreement with the earlier study by (Pankaj and Khadda 2017) reported that the significant increase in the milk yield by 27.65 percent in experiment group and suggested that the supplementation of UMMB improved the milk yield.

In agreement with Mandal et al., (2001) also reported that a positive co-relation between gradually increased UMMB intake and level of milk yield. They further reported that milk yield was $49.76 \%$ higher in UMMB supplementation than in the control group in 140 days experimental period. Result showed that the average increase of milk production of animals found higher in treatment group in comparison to control group 1.08 and -0.63 liter, respectively.

It is clearly indicating that fed mineral block was getting higher production performance and hold her peak yield for longer duration in comparison to control group. Similar findings were also reported by Choudhary et al., (2018) revealed that UMMB and deworming fed dairy animals enhanced milk production from1.0-1.5 liter of the dairy animal. Similarly, Tekeba et al., (2012) also found significantly increased milk yield in UMMB supplemented group as compare to unsupplemented group.

\section{Reproductive performance}

Data in table 3 revealed the effect of UMMB and dewormer on fertility improvement of the experimental cows during the period. Time taken to come in first heat, number of service per conception, service period, number of conceived animals and conception rate was the parameters which were recorded in present experiment to check fertility improvement of experimental animals.

Supplementation of Urea Molasses Mineral Block fed animals (41.4 days) observed for first heat sign 22.4 days earlier than control group (63.8 days). Treatment group also had lower number of AI per conception than the control group. Beside this also service period was found lower in treatment group than control group 68.7 and 103.1 days respectively.

Feeding of UMMB to dairy cattle in their early lactation was able to reduced service period by 22.4 days, which favors the findings of Sahoo et al., (2017) and Puvarajan and Vijayarajan (2013). Patil et al., (2017) reported that Supplementation of urea, molasses and mineral mixture enriched block showed promising results in improving the reproduction performance of animals. In given period, out of 10 animals from each groups 9 and 4 animals were conceived in treatment and control groups, respectively.

Rate of conception was found $50 \%$ higher in UMMB fed group than the control group. These result are agreed with Mazedet. al. (2004) reported that UMMB has a positive effect on fertility of the local cows under the village condition.

Our results were corroborated with the findings of (Pankaj and Khadda 2017)who reported that UMMB supplementation has a positive effect on reproductive performance of zebu cattle. Data for reproductive performance is summarized in graph (Fig. 2) for comparison of different sign between treatment and control group. 
Table.1 Physical Composition of Urea Molasses Mineral Block

\begin{tabular}{|c|l|c|}
\hline S.No. & Ingredients & Percentage (\%) \\
\hline $\mathbf{1 .}$ & Molasses & 40 \\
\hline $\mathbf{2 .}$ & Urea & 10 \\
\hline $\mathbf{3 .}$ & Cement & 5 \\
\hline $\mathbf{4 .}$ & Lime & 5 \\
\hline $\mathbf{5 .}$ & Deoiled rice bran & 20 \\
\hline $\mathbf{6 .}$ & Wheat bran & 10 \\
\hline $\mathbf{7 .}$ & Mineral mixture & 8 \\
\hline $\mathbf{8 .}$ & Common salt & 2 \\
\hline
\end{tabular}

Table.2 Impact of UMMB on milk production performance (liter) of lactating cows at 30 days interval

\begin{tabular}{|c|c|c|c|c|c|c|c|c|}
\hline $\begin{array}{l}\text { Treatment } \\
\text { group }\end{array}$ & initial & $\begin{array}{l}\text { 30 } \\
\text { days }\end{array}$ & $\begin{array}{l}60 \\
\text { days }\end{array}$ & $\begin{array}{l}90 \\
\text { days }\end{array}$ & $\begin{array}{l}120 \\
\text { days }\end{array}$ & $\begin{array}{l}\text { Average } \\
\text { Milk } \\
\text { yield }\end{array}$ & $\begin{array}{l}\text { Increased } \\
\text { milk yield } \\
\text { at } 120 \text { days }\end{array}$ & $\begin{array}{l}\% \text { Milk } \\
\text { yield } \\
\text { Increase }\end{array}$ \\
\hline \multirow[t]{10}{*}{$\mathbf{T}_{1}($ Control $)$} & 6.00 & 6.20 & 6.20 & 5.90 & 5.50 & 5.96 & -0.40 & -8.33 \\
\hline & 5.00 & 5.10 & 5.40 & 5.00 & 4.60 & 5.02 & -0.40 & -8.00 \\
\hline & 7.00 & 7.20 & 7.30 & 6.80 & 6.20 & 6.90 & -0.60 & -11.43 \\
\hline & 6.50 & 6.50 & 6.60 & 7.00 & 5.80 & 6.48 & -1.20 & -10.77 \\
\hline & 5.50 & 5.80 & 5.90 & 5.50 & 4.60 & 5.46 & -0.90 & -16.36 \\
\hline & 6.00 & 6.50 & 6.60 & 6.40 & 5.50 & 6.20 & -0.90 & -8.33 \\
\hline & 7.50 & 7.60 & 7.50 & 7.80 & 7.30 & 7.54 & -0.50 & -2.67 \\
\hline & 6.00 & 6.30 & 6.50 & 6.40 & 5.90 & 6.22 & -0.50 & -1.67 \\
\hline & 7.50 & 7.70 & 7.90 & 7.40 & 7.00 & 7.50 & -0.40 & -6.67 \\
\hline & 6.50 & 6.60 & 6.80 & 6.50 & 6.00 & 6.48 & -0.50 & -7.69 \\
\hline Average & 6.35 & 6.55 & 6.67 & 6.47 & 5.84 & 6.38 & -0.63 & -8.03 \\
\hline \multirow[t]{10}{*}{$\mathbf{T}_{2}$ (Treatment) } & 5.40 & 5.60 & 5.70 & 6.10 & 6.50 & 5.86 & 1.10 & 20.37 \\
\hline & 6.10 & 6.50 & 6.80 & 6.80 & 7.20 & 6.68 & 1.10 & 18.03 \\
\hline & 5.00 & 5.20 & 5.30 & 5.40 & 6.20 & 5.42 & 1.20 & 24.00 \\
\hline & 7.00 & 7.10 & 7.50 & 7.50 & 8.00 & 7.42 & 1.00 & 14.29 \\
\hline & 6.00 & 6.20 & 6.40 & 6.50 & 6.80 & 6.38 & 0.80 & 13.33 \\
\hline & 5.50 & 6.00 & 6.30 & 6.50 & 6.60 & 6.18 & 1.10 & 20.00 \\
\hline & 4.40 & 4.50 & 4.70 & 5.00 & 5.80 & 4.88 & 1.40 & 31.82 \\
\hline & 6.00 & 6.20 & 6.60 & 6.80 & 7.10 & 6.54 & 1.10 & 18.33 \\
\hline & 7.50 & 7.60 & 8.00 & 8.30 & 8.40 & 7.96 & 0.90 & 12.00 \\
\hline & 8.00 & 8.40 & 8.50 & 8.70 & 9.20 & 8.56 & 1.20 & 15.00 \\
\hline Average & 6.10 & 6.32 & 6.58 & 6.76 & 7.18 & 6.59 & 1.08 & 17.70 \\
\hline
\end{tabular}


Table.3 Effect of UMMB and dewormer on fertility improvement in dairy cows

\begin{tabular}{|l|c|c|}
\hline Reproductive Parameters & Treatment & Control \\
\hline First Post-Partum estrous (Days) & 41.4 & 63.8 \\
\hline AI/conception & 1.11 & 1.75 \\
\hline Service Period (Days) $*$ & 68.7 & 103.1 \\
\hline Cow Conceived & 9 & 4 \\
\hline Conception Rate (\%) & 90 & 40 \\
\hline
\end{tabular}

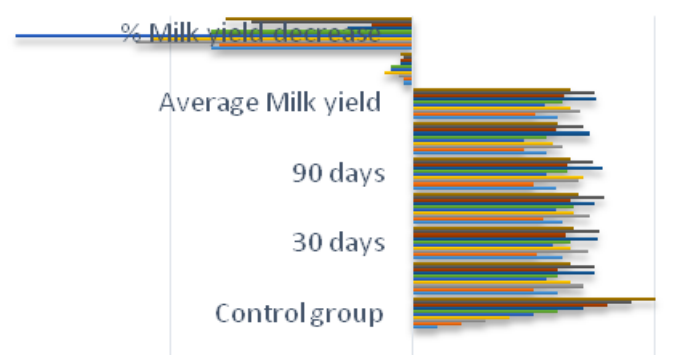

$\%$ Milk yield Increase

Average Milk yield
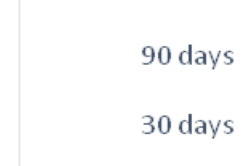

Treatment Group

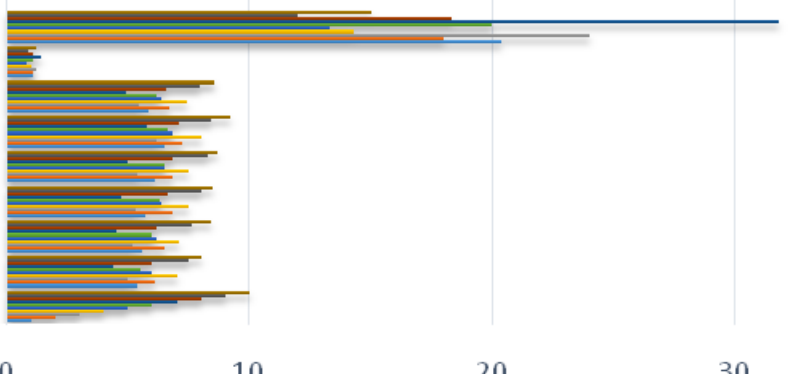

$-10$

10

30

40

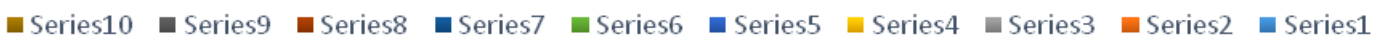

Fig.1 Milk production performance of dairy animals in different groups

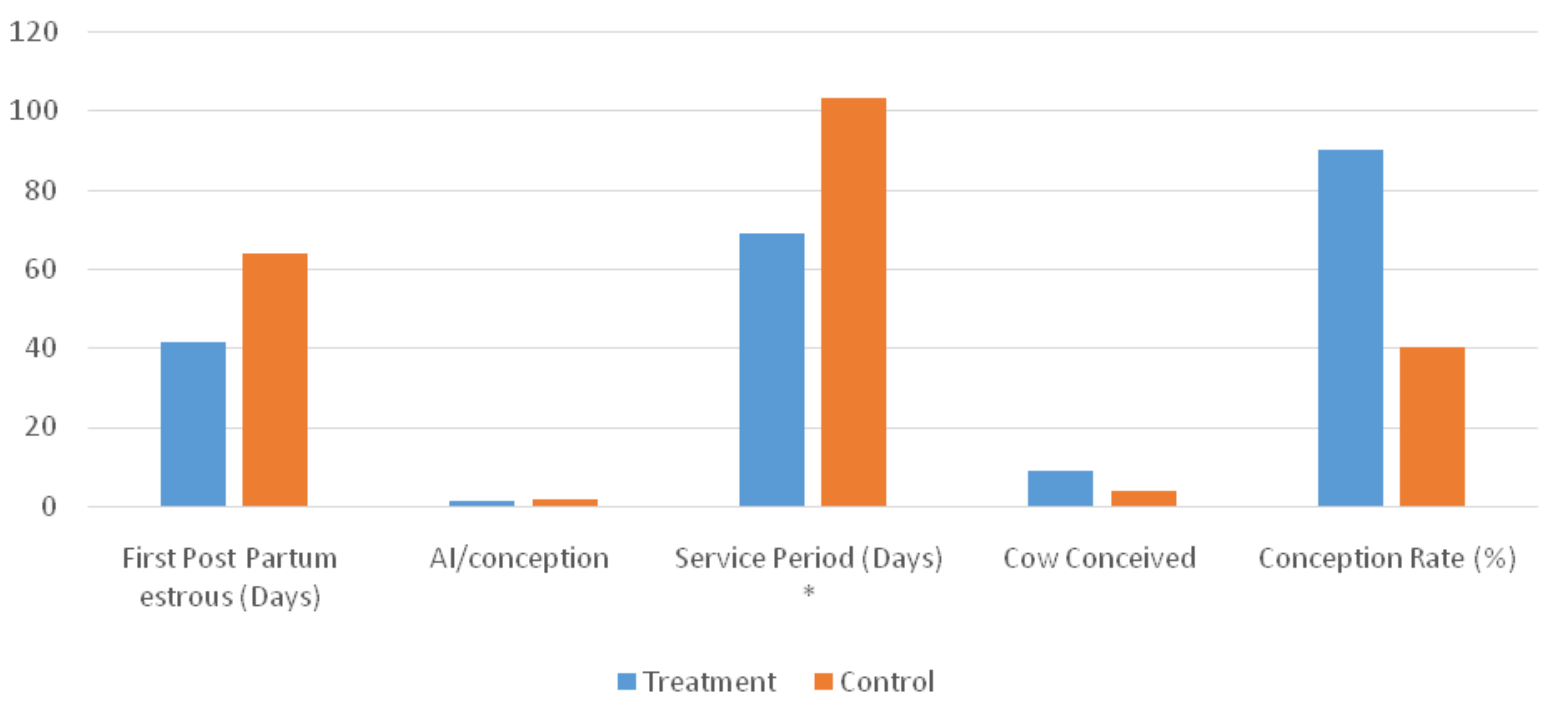

Fig.2 Reproductive performance of dairy cows in different groups 
Livestock is an important source of cash income at the smallholder level. The productivity of dairy cows is greatly constrained by the lack of good quality feed. Hence, it can be concluded that the improvement in nutrient intake, milk yield, onset of estrus in experiment group in cows could easily be achieved as urea molasses minerals block supplied the adequate nutrients for better performance in dairy cows.

In field condition repeat breeding is a major problem in dairy animals. Feeding of UMMB could improve their reproductive cyclicity with mark display of estrus symptoms. It could be recommended that supplementation of Urea Molasses Mineral Block and dewormer in dairy animal improves their production potential.

However, awareness needs to be created among the dairy farmers about usefulness of UMMB. Increases in milk production due to UMMB supplementation have brought additional income while improving reproductive performance, leading to more calves. This has undoubtedly improved the social status of the farmers

\section{References}

Choudhary, Govind Kumar, Chaudhary, R. P., Prasad, Rajendra and Rekha Sing. (2018). Evaluation of Urea Molasses Mineral Mixture Block (UMMMB) and Dewormer for Improvement in Herd Fertility in Dairy Animals - A On Farm Trial (OFT), Int.J.Curr.Microbiol. App.Sci. Special Issue, 7: 149-152

FAO. 2012. Balanced feeding for improving livestock productivity - Increase in milk production and nutrient use efficiency and decrease in methane emission, by M.R. Garg. FAO Animal Production and Health Paper No. 173. Rome, Italy. LawaniaPankaj and Khadda B S (2017).
Efficacy of Urea Molasses Minerals Block on Milk Production and Reproductive Performance of Zebu Cattle under Field Condition. J Krishi Vigyan, 6(1): 83-87

Makkar H (2002). Frequently asked questions on urea molasses-multinutrient block technology (UMMB).Report on review meeting - International Atomic Energy Agency (IAEA) Vienna, Ausria. pp. 116.

Mandal P, Kunwar BS, Shrestha HR and Thapa MS (2001). Technology from bovine research program. Bovine Research Program, Khumaltar, Lalitpur, Nepal.pp. 41-46.

MazedM.A. Islam M.S. RahmanM.M. Islam M.A. and KadirM.A (2004). Effect of Urea Molasses Multinutrient Block on the Reproductive Performance of Indigenous Cows under the Village Condition of Bangladesh. Pakistan Journal of Biological Sciences, 7: 12571261.

Patil, Ashok Kumar, Katole,Shrikant and Agrawal,Vivek(2019).Urea Molasses Mineral Supplement For Enhancing Livestock Productivity. Veterinary Research International.5 (4): 75-79

Puvarajan B and Vijayarajan A (2013). Effect of area specific mineral supplementation in anoestrous cross bred heifers. Indian Journal of Field Veterinarians, 8: 43-44.

Sahoo J, Das S, Sethy K, Mishra S, Swain R, and Mishra P (2017). Effect of Feeding Area Specific Mineral Mixture on Haemato Biochemical, Serum Minerals and Ovarian Status of Reproductive Disordered Crossbred Cattle in Jatani Block of Odisha. International Journal of Livestock Research 7(5): 98-104.

Singh, R. (2009). Mineral Imbalances in Livestock with reference to soil-plantanimal relationship submitted to the Department of Science and Technology, 
Government of India, New Delhi.

Singh, R., S. Kumar, and Brar, P. S. (2010).

Evaluation of urea molasses multinutrient blocks enriched with area specific mineral mixture in buffaloes; Indian Jour of Ani. Sci. 80 (6): 561564.

Tekeba E, Wurzinger $\mathrm{M}$ and Zollitsch $\mathrm{W}$
(2012). Effects of urea-molasses multinutrient blocks as a dietary supplement for dairy cows in two milk production systems in north-western Ethiopia. Livestock Research Rural Development, 24(8): 1-13.

\section{How to cite this article:}

Vivek Pratap Singh, R. P. Singh, A. K. Singh, R. K. Singh, A. K. Srivastav and Upadhyay. S. P. 2020. Impact of Urea Molasses Mineral Block and Dewormer on Milk Production and Reproduction Performance of Dairy Animals. Int.J.Curr.Microbiol.App.Sci. 9(06): 1145-1151. doi: https://doi.org/10.20546/ijcmas.2020.906.142 